\title{
Cosmopolitanism as Discourse and Performance: A View from the Semiperiphery
}

\author{
Ivana SPASIĆ \\ Department of Sociology, Faculty of Philosophy, University of Belgrade, Serbia \\ ispasic@f.bg.ac.rs
}

\begin{abstract}
The paper offers a critical reading of recent literature on cosmopolitanism, from a perspective theoretically informed by Bourdieu and shaped by the experiential and intellectual context of southeast Europe as the semiperiphery. Several blind spots are identified, the most important one being insufficient self-reflection on the part of major contributors, resulting in unintended celebration of what is routinely available to only some parts of the globe and some social strata, and a concomitant devaluation of other humans and their less fortunate lifeworlds. Instead, it is argued, cosmopolitanism should be conceptualized as an embedded category, as a specific discourse and performance deployed by definite actors, addressing a particular audience, and within historically, culturally and politically determined social settings. Seen in this light, it is not necessarily morally laudable and entails its own exclusions and injustices.
\end{abstract}

Key words: cosmopolitanism, semiperiphery, universalism, discourse, performance, distinction

\section{Introduction: the cunning of cosmopolitan reason}

Over the past decades, many binary oppositions have been dissolved, and most variants of "othering" have fallen into disrepute in the social sciences. ${ }^{1}$ Ways of talking about entire categories of people that once figured as just descriptive have correctly been exposed as deeply evaluative. It has become theoretically and morally untenable to position the objects

\footnotetext{
${ }^{1}$ The idea for this paper arose from the project "The Challenges of Europeanisation: Mediating between National and European Identities in South Eastern Europe" (SEUM, 2010-2011), sponsored by ASO (Austrian Science and Research Liaison Office), Ljubljana (www.seumproject.eu). I wish to thank team members, especially Ksenija Vidmar Horvat and Mirko Petrić, for the many fruitful conversations we have had. The present version of the paper is part of the project "Challenges of New Social Integration in Serbia" (No. 179035), supported by the Ministry of Education and Science of Serbia.
} 
of social scientific discourse on the negative side of scales of aesthetic, cultural, and moral evaluation, with the speaking and writing subject locating him or herself - mostly himself, actually - at the other side. From a certain point in time on, one was no longer supposed to treat in this way women, or the working class; then came the Blacks, ethnic minorities, lesbians and gays; Third World peoples, the disabled, the illiterate; and ending with fans of trash media stuff, celebrated by the more populist strand of cultural studies. Over the past four decades roughly, sociologists, if siding at all, have almost invariably sided with the underdog, as if Howard Becker's old formula (Becker, 1967) has been progressively broadening its reach.

But one binary strangely survives, and goes largely unexamined. It is the opposition between "cosmopolitanism" and its contrasting terms, such as xenophobia, closure, localism, or nationalism. In this juxtaposition, cosmopolitanism is, quite simply, treated as positive: it is discursively asserted, cared about, and defended from threats; cosmopolitan persons, practices, thoughts, and artefacts are more or less openly praised. In the background there is a broader set of binary oppositions, where adjectives such as open, enlightened, progressive, global, diverse, contemporary, inclusive, is contrasted with closed, isolated, homogeneous, conservative, local, autistic, and intolerant. An unstated yet all-but-obligatory consensus, or "premise of a shared understanding" (Vidmar Horvat, 2011b: 1), is established between writer and reader that this indeed is "our" side. This usually comes as no conscious intention of either; but the way the reader is drawn into the consensus, without even noticing, does not mean the process is not taking place. Rather, it indicates a basic fact: most of "us", social scientists, after all, consider ourselves cosmopolitan. We prefer the cosmopolitan attitude and the corresponding values and, believing this kind of stance to be ethically superior to its alternatives, we readily, sometimes passionately, embrace it as our personal choice. True enough, it is hard to be hard on oneself, and the cosmopolitan stance has escaped thoroughgoing critical scrutiny at least partly because "it is enunciated from a position that self-identifies as the subject of the research process, the intellectual elite" (Friedman, 1997: 72). As a result, no one seems to be noticing the fact that in this case the sociologist ends up siding with the dominant rather than the underdog.

Since it is "us" who are the problem here, we are facing the imperative of thinking through these binaries and to beware of easy identifications. In a welcome admonition, two Canadian authors remind us that what appears obvious and taken-for-granted ought to provoke an immediate sceptical response of our sociological instinct. And indeed, "the mass adoption 
of the value of diversity and cosmopolitanism in fields so wide apart as marketing, education, and the social sciences suggest that a new common sense is gradually being established" (Fridman and Ollivier, 2004: 116). This circumstance, however, has for the most part failed to stir much interest among otherwise critically minded social thinkers.

\section{The cosmopolitan revival}

In the past twenty years, the notion of cosmopolitanism has proved increasingly attractive to thinkers in a wide range of disciplines. At the beginning of this revival stands the important exchange prompted by Martha Nussbaum's essay on "patriotism and cosmopolitanism" and published as a dialogic collection of pieces (Nussbaum, 1996). The interest grew still more intense after the turn of the millennium, and witnessed a proliferation of books, journal papers and conferences over the last decade. ${ }^{2}$

Cosmopolitanism is being thematized in a wide variety of scholarly contexts. In philosophy, it has been associated mostly with ethics, the idea of moral obligation, and the universalization of values. Political theory, political science and the study of governance have treated cosmopolitanism as related to issues of global democracy, the global human rights regime, institutional and practical transnationalization, especially EU integration, as well as accommodating multiculturalism within societies. Anthropology, along with human geography and cultural studies, has dealt with it predominantly as a question of increasingly shifting identities, being reinvented and hybridized at both individual and collective levels through migration, tourism, consumption, media, and popular culture. The attempt to forge a "methodological cosmopolitanism" has been distinctive for sociology.

The argument I wish to develop in this paper overlaps with several important discussions within this vast literature, but is not fully contained in any of them. To begin with, there is the question of how globalization and cosmopolitanism are connected: do they imply one another, or not necessarily?3 A related discussion, launched by Ulrich Beck (Beck, 2002,

\footnotetext{
2 Major contributions include: Vertovec and Cohen (2002); Delanty (2009); Beck and Grande (2006); Kendall, Woodward and Skrbis (2009); several special issues of major journals, such as Theory, Culture \& Society, 19 (1-2), 2002; British Journal of Sociology, 59 (1), 2006; European Journal of Social Theory, 10 (1), 2007; and special sections, e.g. Current Sociology, 53 (1), 2005. As many as five books on topics related to cosmopolitanism published within just two years (2007-2009) are reviewed by Fossum (2011).

${ }^{3}$ Roudometof (2005) addresses explicitly the relation between transnationalism and cosmopolitanism; his propositions are put to empirical test in Olofsson and Öhman (2007), with further refinement in Pichler (2009).
} 
2004; Beck and Sznaider, 2006; Beck and Grande, 2006), concerns the prevalence of "methodological nationalism" in social science and the need to overcome it. ${ }^{4}$ Finally, my analysis comes closest to a concern with the "elitist bias" of the cosmopolitan project - the issue of cosmopolitanism's class base, and whether it only involves privileged social strata. The more or less salient elitism of the cosmopolitan figure has been pointed out by a number of authors (Bauman, 1998; Friedman, 1997; Calhoun, 2002, 2003, 2008; Szerszynski and Urry, 2002; Vidmar Horvat, 2011a, 2011b). ${ }^{5}$ How my discussion relates to this issue will be taken up later on.

Although all these rich and thoughtful debates significantly inform my discussion presented here, I have in mind something else, that continues to be missing. This omission involves two interrelated aspects: one is absence of self-reflection on the part of the producers of cosmopolitan discourse, and the other is a failure to conceive cosmopolitanism in a sufficiently embedded, situated and contextualized way.

\section{Tackling cosmopolitanism}

The cosmopolitan idea dates back to antiquity, with Greek cynics and Roman stoics, to be developed into its modern forms, of which Kant's universalist enlightenment version is the most important, and further to the more complex 20th century approaches. ${ }^{6}$ Most generally speaking, cosmopolitanism is associated with a stance of openness to the world, especially the (cultural, religious, ethnic) Other; with an ethical commitment to universal values, and obligation to humanity as a whole rather than one's kin and compatriots; a willingness to engage in conversation across boundaries of identity, seeking points of connection and sharing; a receptivity towards divergent cultural experiences. It is also described as "globalization within" (Ulrich Beck) and "globalization in the head" (Roland Robertson). Whatever the definition, the concept revolves around two poles: universalism and diversity. "Cosmopolitanism is, in a slogan,

\footnotetext{
${ }^{4}$ While most authors are sympathetic with Beck's calls to broaden the grasp of social scientific explanation, some reject the claim that classical theory was methodologically nationalist (e.g. Chernilo, 2012; Kendall, Woodward and Skrbis, 2009).

${ }^{5}$ Skrbis and Woodward (2007: 731) go as far as to say that "the motif of the cosmopolitan as privileged, globally mobile, and capital-laden, is the dominant image in cosmopolitan studies". I disagree. It is true that the connection with class is sometimes made, but the concern is minoritarian within the literature as a whole.

${ }^{6}$ A good overview of the concept's history, highlighting similarities and differences between a "classical", more universalistic, and a "contemporary", more difference-sensitive and self-critical cosmopolitanism, is offered in Delanty (2009: 18-88).
} 
universality plus difference", writes a major contemporary reviver of the concept (Appiah, 2007: 151). Although equally indispensable, these are two distinct aspects indeed, ${ }^{7}$ and their dualism gives rise to considerable confusion (Calhoun, 2008: 429).

Vertovec and Cohen (2002: 8-14) usefully distinguish between six different meanings in which "cosmopolitanism" is used: 1) a sociocultural condition: a set of structural (social and cultural) changes brought about by globalization; 2) a philosophy and worldview which seeks to embrace diversity; 3 ) a political project of international cooperation, and 4) of allowing for multiple affiliations and solidarities of citizens of the global civil society; 5) a set of attitudes, stressing openness towards the world and recognition of difference; 6) a set of competences and practices: specific behaviours and skills enabling people to participate in different cultures, understand diverse social meanings and reflect upon their own cultural repertoires. To this we may add a distinction, partly cutting across the proposed typology, between a self-professed, conscious, explicit, "subjective" cosmopolitanism - "I am cosmopolitan" - and practices that could be interpreted and labelled by others as "objectively" cosmopolitan.

Against this brief conceptual outline, in this text, as already announced, I would like to interrogate a double omission in the cosmopolitanism literature. Firstly, the term is mostly used uncritically and unreflectively. Although its plural meanings are acknowledged, it is still treated as something "good", and the speaker him/herself is not introduced into the picture. Secondly, cosmopolitanism is usually lifted out of its social context and the term is treated as an abstract, generally valid label that may be applied to certain entities, regardless of differences in social settings, and contrasted with some other entities, supposedly just as easily identifiable as non-cosmopolitan. ${ }^{9}$ It is my contention, on the contrary, that cosmopolitanism is an

\footnotetext{
${ }^{7}$ They receive different emphases from various authors, with political philosophers, on the whole, tending to prioritize "universalism" (e.g. Nussbaum, 1996; Waldron, 2000), while sociologists and cultural theorists mainly stress "diversity" (Beck and Grande, 2006, 2007; Szerszynski and Urry, 2002; Hannerz, 1990), although the universalist theme has lately been reintroduced (e.g. Chernilo, 2012).

${ }^{8}$ It is interesting to note, with Kendall, Woodward and Skrbis (2009: 2), that while the ultimate value of globalization is contested, there is no comparable ambivalence about cosmopolitanism.

${ }^{9}$ The number of works that largely manage to avoid this pitfall is surprisingly small, and includes Woodward and Skrbis (2006), Skrbis and Woodward (2007), Antonsich (2008), Lamont and Aksartova (2002), Szerszynski and Urry (2002). It is probably no coincidence that in all these instances the analysis is firmly based on empirical data, and of a qua-
} 
embedded notion, which always functions within a definable social context, where it necessarily obtains some specific shades of meaning and implications that it may not have elsewhere. It is not a neutral descriptive term, although it is often treated as such. Instead, cosmopolitanism is a kind of language, used by some definite speakers, within a particular genre, intended for an audience - whether actually present or envisaged, and against a backdrop of shared assumptions. Asking questions about all these elements are indispensable parts of a sociological treatment of cosmopolitanism. Instead of accepting it a priori as an analytical category, "we had better ask ourselves who has resorted to this concept, when, for what purposes and with what results", as Diana Mishkova (2008: 252) says about the comparable concept of "Europe".

Cosmopolitanism necessarily involves a discursive practice of (self) labelling and classifying, and a performative practice of "being" cosmopoli$\tan$ (or not); and in addition to Kantian bird's-eye view of universal morality it importantly operates within living, dynamic, hotly contested social spaces, where being called a cosmopolitan, or on the contrary, a patriot, xenophobe or local matters very much, affects the lives of real people, opens up or closes prospects for them, enhances their symbolic capital, improves their chances with this political force rather than that one, brings them pecuniary benefits or sends them to jail, and so on. These matters are not to be taken lightly, for either moral or theoretical reasons.

True enough, there are exceptions to these omissions. In his insightful text on "cosmopolitan openings and closings" in post-Yugoslav societies, Jansen calls for exploring "how cosmopolitanism may function as a resource" (2009a: 76). From a different perspective, Woodward and Skrbis (2006) identify a strategic cosmopolitanism, while Weenink (2008) sees cosmopolitanism as a form of capital. It is this strand of inquiry that I wish to continue.

The aim of this paper will be to engage recent sociological writings on cosmopolitanism with a critical eye on the ways the concept is used. I will have in mind the Bourdieusian concern with the "social conditions of possibility" of, or unequal distribution of access to, certain outlooks and practices, in this case, "cosmopolitan" ones. This uneven availability

litative sort. Undoubtedly, however, it is the approach developed by Craig Calhoun in a series of articles $(2002,2003,2008)$ that comes closest to what I am trying to do here. He skilfully reads instances of public discourse, including social scientific one, to show how cosmopolitanism is moulded by social position and global distribution of symbolic power. The main difference is that in his treatment the embodied location of his own authorial voice is less important, and hence remains less fully specified. 
is manifested internally, within societies, as well as internationally, between societies. Both of these paths will be taken up in what follows, as they both impinge on the valences of cosmopolitanism as an embedded phenomenon.

To bar any possible misunderstandings, I wish to stress at the outset that I am not arguing "against" cosmopolitanism and "for" any kind of localism, especially not any kind of nationalist isolationism. Precisely because of myself identifying personally with a cosmopolitan position, the urge to look for ways of endorsing cosmopolitanism in a more responsible and equitable way animates the present analysis.

\section{Why semiperiphery?}

My perspective will be situated in the ex-Yugoslav region, southeast Europe, or "Western Balkans" as we are now expected to call ourselves. ${ }^{10}$ By "semiperiphery" I am not referring so much to the original meaning of the term as it was coined within world systems theory, where it indicates a nation's intermediary position in the global distribution of economic assets. What I have in mind rather is a "softened" version of the concept, developed recently by Marina Blagojević within her proposal for a critical sociology of knowledge (2009). The focus is on symbolic, cultural and cognitive aspects of global stratification: intellectual hegemony, unequal capacity of defining self and other, and collective stigmatization.

In this reading then, the semiperiphery is a space located close to the core yet not the core itself, always "lagging behind" yet not distant enough to develop an alternative scale of evaluation, hence forever measuring itself with the yardstick of the core. Positioned between the centre and the periphery, it has characteristics of both. It cannot be subsumed under the postcolonial subject, because, from the viewpoint of the periphery, it is "too white", too industrial, too developed, and, most importantly, not eligible for claiming victimhood due to the absence of colonial experience (Blagojević, 2009: 38). In its Balkan version, it is Europe's "internal Other" (Todorova, 1999). As "non-'White' whites, non-European Europeans" (Blagojević, 2009: 27), the inhabitants of the semiperiphery have the option of recognizing themselves (partly) in Western "superiority", but, not being "white" enough, they cannot help feeling their collective self to be chronically deficient.

Semiperiphery may be seen as being located at the intersection of major geosymbolic coordinates - West/East, and North/South, with its position shifting on both axes. As a result, it often ends up in a kind of

\footnotetext{
${ }^{10}$ An incisive analysis of media treatment of this phrase may be found in Petrović (2010).
} 
void, as simply forgotten. In spite of its heuristic potential, it is almost completely overlooked in the cosmopolitanism literature as well. Recent works sometimes take pains to distance themselves from the overt or covert Eurocentrism of earlier approaches, explicitly including a discussion of "non-Western", "vernacular”, Asian, "Southern” etc. cosmopolitanisms (Werbner, 1999; Pollock et al., 2000; Appiah, 2007; Delanty, 2009), but the European fringe, and other semiperipheral regions of the world, once more remain invisible. When Delanty (2009: 245-247), for example, talks about the "periphery" of Europe, meaning its East and South-East, he leaves out of sight that Europe's periphery is globally semiperiphery, since Europe as a whole is core for most of the rest of the world, which fact complicates considerably this region's relation to its own core.

The particular inflection of "cosmopolitanism as discourse and performance" in the semiperiphery is extremely interesting, thanks to a whole set of important circumstances. In these generally not very rich or powerful societies, "opening up" that cosmopolitanism implies has traditionally meant an opening up to the powerful, dominant Other, the West - sometimes enemy, sometimes ideal, but in any case the most significant reference point in cultural and identity struggles. Furthermore, Eastern Europe is marked by an additional experience setting it apart from the European core - the actually-existing socialist past, including its specific legacy of "socialist internationalism" interpretable as a kind of cosmopolitanism. Narrowing the focus down to the "Western Balkans", finally, what makes the region especially intriguing for the present topic is that in the last decade of the 20th century it took a course contradicting the general trend: instead of a relativization of nation state taking place elsewhere, here states were multiplying, dreaming of absolute sovereignty and national purity, and seeking to make their borders as impermeable as possible. While international migration and travel rose to unprecedented levels globally, in parts of the "Western Balkans" the disappearance of the Yugoslav "red passport" (Jansen, 2009b) meant effectively the disappearance of the very possibility to move.

Within the region, Serbia is particularly marked by its deeply disparate and contradictory legacy. On the one hand, it inherits a long tradition of engagements with the outside world, especially cultural and political borrowings from the West, and the experience of being part of the "cosmopolitan" SFR Yugoslavia. On the other hand, the country was in international isolation throughout the 1990s and has not yet fully recovered from the burdens of war involvement and war crimes; at this moment, it is torn between two master political-cultural orientations - a "pro-European" one, and a nationalist isolationist one. Although my perspective will be coloured by the Serbian 
experience, hopefully what I have to say will be of broader significance and speak to the situation in other semiperipheral settings as well. ${ }^{11}$

\section{A Bourdieusian reading of the literature}

Let me begin by noting a conceptual parallel. In his sociological theory, Pierre Bourdieu treats universalist claims as a stake in the social (power) game, wherein actors, pursuing noble principles, work also, and largely unintentionally, towards their own benefit. He identifies a generic "interest in disinterestedness" (Bourdieu, 1994: 147-172) across different spheres of social practice: in the artistic field, as the "pure aesthetics" which claims to be a matter of individual inspiration (Bourdieu, 1979: 565-585); in politics and law, as the bureaucratic ethos that takes pride in giving precedence to the common good over narrow interests (Bourdieu, 1994: 99-146); in linguistic behaviour, as legitimate language competence that is officially, but not factually, open to all who care to acquire it (Bourdieu, 1982); in academia, as the scholarly quest for truth, which at the same time well serves scientists' careers (Bourdieu, 1997, 2001); in social scientific vocabularies, as the circulation of falsely universal concepts and topics whose particular genesis within a specific context has been neutralized (Bourdieu and Wacquant 1999).

With its universalist reference - the call to shed the constraining shackles of particularist commitments to locality, ethnicity, and nation and to develop a sense of allegiance to humankind, cosmopolitanism may be read through the same lens. Like the artistic "beautiful", the scientific "true", or the bureaucratic "common good", cosmopolitanism has a ring of nobility, selflessness and moral superiority around it. Yet it may, and often does, bring profit to its champions. Cosmopolitanism, like the other forms of the universal, is undergirded by a double tension: between the nobility of the cause and the accruing benefits, and between the claimed universal availability and the factual inequality of access. As two among the very few writers recognizing this homology say, "conspicuous openness to diversity functions as cultural capital, in the Bourdieusian sense of a cultural element widely recognized as desirable but whose conditions or appropriation are unequally distributed in the social space" (Fridman and Ollivier, 2004: 107).

Bourdieu (1994) insists that the conditions (dis)favouring the development of universalist potentials are differentiated along lines of social po-

\footnotetext{
${ }^{11}$ Which parts of the world exactly belong to the semiperiphery remains debatable. But since the label confers no special benefits - neither the power nor prestige of the core nor the moral value of suffering of the periphery - it seems safe to treat it as an open and generous category: whoever feels to be part of it is welcome.
} 
sition, and across societies. What he does not see clearly enough is how these two planes interact, producing what recent feminist theory has aptly called "intersectionality". The semiperipheral perspective helps us grasp to what extent these are two interrelated, mutually shaping dimensions produce their effects jointly, and may be analyzed only as such. To anticipate what will be argued later on, in the "Western Balkans" cosmopolitanism is relatively strongly associated with social privilege and specific self-positioning of groups claiming elite status, precisely because of the region's particular location on the global geosymbolic map - which in turn reflects international imbalances of economic wealth, political power, and military might. In addition, in the region discourses and practices interpretable as cosmopolitan can hardly be banal and routine, eschewing political and ideological readings. Willingly or not, actors engaging in such practices are seen as manifesting a political choice. This of course is not to say that such connections are non-existent in the West, but they are much less salient and less inevitable.

A critical gaze informed by Bourdieu's ideas then may offer a fresh reading of recent cosmopolitanism literature. Discussions of cosmopolitanism almost invariably contain a normative element - "cosmopolitanism is both description and normative program and the distinction is often unclear" (Calhoun, 2008: 429) - and the problem is that it sometimes pops up where it was not intended, or in less than laudable forms. An aim of my reading will be to point to instances of such "surreptitious" normativity.

Let us begin, appropriately enough, with Ulrich Beck, arguably the leading cosmopolitanism author in sociology over the past decade. Among Beck's many pronouncements on the topic, one phrase has by now become emblematic: "Not all, but an increasing number of people nowadays trade internationally, work internationally, love internationally, marry internationally, do research internationally, and their children are growing up and are being educated internationally" (Beck, 2002: 31). He wants to say that the inhabitants of today's world live in an environment of increasing movement, melting, mixing, and subversion of boundaries. Whether this declaration is class-biased remains a moot point - some think it is (e.g. Lamont and Aksartova 2002: 2), others believe it is not (e.g. Werbner, 1999) - but this is not my concern here. Instead I would like to show that it is insensitive to differences deriving from global locationality.

In what is presented as an attempt to move away from the elitism of the traditional receptions of cosmopolitanism that tied it to intellectual abstraction and free choice of higher social strata, Beck argues for the importance of a "banal cosmopolitanism", the increasing internationality 
of ordinary people's daily experiences, arising from an impersonal, objective, unintended process he names "actually existing cosmopolitanization" (Beck, 2004: 133-134). Upon closer inspection, however, Beck's "banal cosmopolitanism" appears to be enclosing some new, surreptitious differentiations. It is described, for example, as the pervasiveness of "black culture, styles and creativities" throughout the world; then, "the huge variety of meals, food, restaurants and menus routinely present in nearly every city anywhere in the world" (Beck, 2004: 150). In another paper, Beck's geographical grasp is somewhat more modest, so that we find "the manycoloured mixtures of food, drinks, nourishments, restaurants, menus, music, etc. that characterize the cities all over Europe" (Beck and Grande, 2007: 72; all emphases added). Beck argues that "everyday nationalism" is being circumvented and undermined as we experience ourselves integrated into global processes and phenomena, including youth cultures, TV and internet, food and drink, that inescapably affect and shape daily cultural practices of millions today (Beck, 2002: 28). This, however, is simply not true of everybody's experience: not all people live in cities, even less in European cities, and not all European cities are so cheerfully multicoloured. Then, "the supermarket around the corner", writes Beck, displays foodstuffs from all parts of the world, and we have grown accustomed to it. The result is "a banal cosmopolitan culinary eclecticism, which is meanwhile promoted and celebrated in cook books and TV food programmes as the new normality" (Beck, 2002: 28). But normality for whom? ${ }^{12}$ Beck continues: "Anyone who still wants to raise the national flag, when it comes to food, founders on the ever more hollow myths of national dishes" - which does not make these dishes any less "national", or dear, to their eaters, one is tempted to add - "which at best are no more than islands in the broad stream of the dominant and by now banal culinary cosmopolitanism" (Beck, 2002: 28). Now, we can be pretty sure this is true of Germany, and many other similar places. But in, say, Hungary already, let alone Armenia, or Kosovo, is it really so? In such settings, familiarity with "banal culinary cosmopolitanism" is necessarily a phenomenon coloured by class, probably also by political and ideological persuasion. And as such, it is a practice that divides people rather than uniting them in a generalized celebration of mixture and crossfertilization. And this divisive quality may prove to be its more significant

\footnotetext{
${ }^{12}$ I must confess that the supermarket around $m y$ corner displays an international selection of foodstuffs only slightly more variegated than what was available in times of my childhood, forty years ago, when the local socialist supermarket chain featured Guatemalan bananas, Asian fresh pineapple, Indian-British Lipton teas, German ham, and Chinese canned pork. Lipton Tea is, actually, much harder to find these days.
} 
feature than the routine participation in the cosmopolis. This at least is how it works in Serbia. In these quarters, it is not routine at all to cook Korean dishes for the family dinner, or have a tortilla for lunch: eating foreign is a marker of social distinction.

Not to keep Beck alone: in one of the first important statements in the current cosmopolitan revival, Ulf Hannerz defines cosmopolitanism as "an orientation, a willingness to engage with the Other [...] an intellectual and aesthetic stance of openness toward divergent cultural experiences, a search for contrasts rather than uniformity" (1990: 239). For Hannerz, cosmopolitanism is strongly associated with individual "sense of mastery". Even if a cosmopolitan may choose to surrender to an alien culture, this also is a sign of mastery, since it implies personal autonomy vis-à-vis his/her culture of origin: "He possesses it, it does not possess him" (Hannerz, 1990: 240). The question is, who can claim such far-reaching autonomy for him or herself? Who has sufficient resources at his/her disposal to survive dissociation of self from its original lifeworld? As Calhoun (2003: 537) reminds us, "differential resources give people differential capacities to reach beyond particular belongings to other social connections. [...] Not only options, but needs for solidarities are unequally distributed". Can we really believe that the poor, the unfortunate, the disorientated, the resentful - laid-off workers of former socialist industrial plants, for instance - can easily afford this sort of emotional luxury?

In their introduction to a journal special issue on cosmopolitanism, Fine and Boon (2007: 9) write that "cosmopolitanism is a demanding and difficult way of life". But isn't it necessary to have the rest of one's life not "demanding and difficult", that is, to have a decent minimum of living standard ensured so as to engage in reflecting at all on what kind of life one wants to lead, let alone go for the "demanding and difficult" cosmopolitanism? In a similar vein, Kendall, Woodward and Skrbis describe the cosmopolitan as a person "who finds ambiguity and uncertainty challenging and interesting" (2009: 153). Wouldn't we say that a person must have some basic needs and necessities fulfilled in order to be able to find ambiguity and uncertainty rewarding, rather than confusing and scary? Like in so many other instances of discussing cosmopolitanism, the problem again is that what is presented as a personal, willing choice - a freely espoused attitude, a set of values embraced, a self-chosen orientation - rests, like anything else humans do, on specific social foundations. Bourdieu would surely gladly remind us at this point, that dependence on social position especially tends to be misrecognized in a "scholastic situation, that is, among people ready to join in the forgetting of the presuppositions inscribed in their common privilege" (1994: 227). 
Whereas this could be called insensitivity, the same deficit in self-reflection may also result in a different kind of problem: paternalism. In Bryan Turner's "cosmopolitan virtue", for example, the principal component is "irony, because the understanding of other cultures is assisted by an intellectual distance from one's own national or local culture". This demands a certain "self-reflexivity with respect to both our own cultural context and other cultural values" (Turner, 2002: 57). Although the expected outcome is a "humanistic scepticism towards the grand narratives of modern ideologies", it is apparently only modern ideologies, and not ideologies as such, that are seen as ripe for deconstruction, since Turner goes on to say that "scepticism and distance from one's own tradition are the basis of an obligation of care and stewardship for other cultures" (2002: 57) - that is, "other cultures" may happily continue to cherish their ideologies, and should be assisted in that. And who is caring here? Clearly, "we", participants in the implicit consensus or the "premise of shared understanding" of academic writers-and-readers, deeply and unselfconsciously Western. More patronizing is yet to come, since "[i]f cosmopolitans are urbanites, they have a special responsibility towards aboriginal cultures arising from an awareness of their precarious condition" (Turner, 2002: 57). It is quite obvious that a reader from an "aboriginal culture" is not foreseen here: the audience addressed is that of Western academia. If it is said that cosmopolitan virtue as a "set of obligations" derives from a "recognition of the vulnerability of persons and the precariousness of institutions with the globalization of culture" (Turner, 2002: 57), it is clearly not the vulnerability of Western persons - because they are required to be ironic, self-reflective, and coolly distanced from their native cultural milieus. Who needs, and will duly get, "our" understanding for the difficulty of their position is "them" - the aboriginals, the far-away, the precarious, the non-modern. There are, then, subjects, and objects of cosmopolitanism; the two categories do not mix or overlap, and it is clear at which side of the divide the speaker of this performative discourse falls. Matters get even more complicated with the insertion of the unanticipated semiperipheral reader: where do $I$ fall? Is my (Serbian) culture "aboriginal" or not? If it is, then effectively Turner wants to say I cannot be cosmopolitan, however much I try. And also if it is, would "care and stewardship" in this case entail an understanding for such things as Serbian collective narcissism and the megalomania of nationalist myths? If not, why do I not recognize myself in this call to care and steward for other cultures? I for my part would like to be "ironic and distanced" towards "other cultures" just as well as towards my own, because I would like to treat them as equals. 
Let me conclude this section with another aspect that my chosen standpoint helps make more transparent. The semiperipheral perspective has an inbuilt reminder of the importance of international mobility - or better, restrictions thereof - for the realization of cosmopolitan potentials. Not all are equal in front of border controls: holders of some passports are subject to a highly restrictive regime of international travel, implying time-consuming and humiliating procedures and high risk of not being permitted to cross the border at all. This fact by itself, quite independently of the actor's outlooks or values, bars a "natural" feeling of "belonging to the world": however cosmopolitan their initial intentions or self-understanding, the ascriptions and restrictions these travellers are confronting constantly remind them "that at least certain sorts of cosmopolitanism are not for them" (Calhoun, 2003: 543). ${ }^{13}$ Other authors tend to forget about this. In their model expressly designed to avoid the limitations of a simplified notion of cosmopolitanism (class bias, irresponsibility, devaluation of the local), the otherwise cautious Szerszynski and Urry (2002: 469) make the model's very first point to be an assumed "extensive international mobility".

\section{Cosmopolitanism as discourse and performance in the semi- periphery}

What is probably true anywhere becomes more visible perhaps in the semiperiphery: realizing cosmopolitan potentials means performing cosmopolitanism - performing as cosmopolitan - and this in turn means playing a specific role in a given setting, with attendant risks and profits. If you do that, for example, in the societies of the southeast European semiperiphery, you will be hated by the xenophobic "patriots", but you will recommend yourself to the "pro-European" liberals. Moreover, cosmopolitanism here manifests itself in a specific guise: while at one side displaying the requisite open-mindedness, it entails a whole set of systematic exclusions at the other. One kind of these exclusions take place externally, beyond the boundaries of nation, and involve closure towards neighbouring peoples in what has been described as a series of "nesting Orientalisms" (Bakić-Hayden, 1995) or "gradients of depreciation" (Živković, 2011) that flow roughly in the northwest-southeast

\footnotetext{
${ }^{13}$ We must note, with a sigh, that Calhoun, too, obliterates the semiperiphery: after 9/11, it is said, the "holders of European and American passports" continue to move as freely as before, while "most others in the world" face restrictions (2003: 543). Calhoun sees Asians, Africans, and Latin Americans who face barriers, but fails to see "non-European Europeans" who fare the same - and resent it probably even more, because, being "white", they often feel somehow "more entitled", and because they usually have a much better past to remember.
} 
direction. The other arena for exclusion is the internal one, where opening up to the wide world implies closing down towards the "uncultured" neighbour - the one without much education, cultural competence, or taste, and the one supposed (usually with a good reason) to be inclined to nationalism and xenophobia. This is not simply a matter of cosmopolitan "class bias": it means that playing the local, contextual stakes in the social game cannot be avoided. Even if we take it to be primarily an individual moral decision, we must be aware that being cosmopolitan, in the Balkans at least, involves a whole package of loyalties and alliances, as well as hostilities and distances. One may choose to embrace a cosmopolitan outlook, but along with it one cannot help "buying" the rest of the package - if not in one's own eyes, than certainly in the eyes of others around.

Research has amply documented how this works. Studying Serbian and Croatian antinationalism in the 1990s, Jansen (2009a) identified a set of homologous dichotomies operative in the cultural world of local cosmopolitanism: "our side" is pro-Western/European (vs. Balkan), educated (vs. illiterate), autonomous/individualist (vs. conformist/collectivist), gender equal (vs. patriarchal), tolerant (vs. exclusivist), peaceful (vs. violent), sophisticated (vs. boorish), etc. While cosmopolitanism rejected othering in national, ethnic, and religious terms, it developed remarkable hostility towards its own Other, defined in terms of cultural competence, lifestyle and ideological standing. Živković (2011) arrives at almost identical conclusions. In the large-scale qualitative study "Politics and Everyday Life" (Golubović, Spasić and Pavićević, 2003), we showed that in Serbia in the early 2000s a cosmopolitan orientation figured prominently in the discourses of cultural distinction whereby interviewees sought to mark the boundary between self and other, as part of the equation culture = urbanity = openness $=$ cosmopolitanism (Spasić, 2006). ${ }^{14}$ Marina Simić's (2010) welleducated young informants from the mitteleuropäisch Serbian city of Novi Sad used cosmopolitanism as a discursive weapon against rural migrants,

\footnotetext{
${ }^{14}$ It should be borne in mind though that this refers to the "explicit" cosmopolitanism of a self-characterized "openness to the world". At the same time, many other interviewees, with modest education and equally deprived of other assets, displayed an "implicit" cosmopolitan potential by asserting human commonality and equality, and by showing some readiness to universalize their moral judgment beyond the boundaries of their own group. In an interesting parallel to Lamont and Aksartova's (2002) argument, the universalist dimension of cosmopolitanism proved here to be more pliable to a popular reworking than the revelling-in-diversity dimension. What this possible "popular cosmopolitanism" can consist of and how it relates to the Bourdieusian issue of "monopoly of the universal" remains to be explored, but it is clear that it differs fundamentally from Beck's "banal cosmopolitanism”.
} 
refugees and other "peasants" whose cultural deficit was also perceived as a moral one ${ }^{15}$ In their quantitative study of cultural preferences in Serbia, Cvetičanin and Popescu (2011) found a master opposition between "global" and "local" types of cultural capital, correlating strongly with social structural variables.

The motif of urbanity is related to another regional feature: in the Balkans, the categories of "local" and "national", rather than blended together and jointly opposed to the "cosmopolitan" as is customarily done, more often pull in divergent directions. Under the pressure of national homogenization amidst interethnic enmities and war from the early 1990s on, a strong "local" identity, a sense of belonging primarily to one's own city - especially the large urban centres of Zagreb, Sarajevo, and Belgrade - has been a mark of resistance to an exclusive national identification. In this case, it is the locality that becomes "cosmopolitan" and competes with the national affiliation, ostensibly more encompassing but felt to be more stifling, more authoritarian - more "provincial".

There are also other contextual circumstances that add new twists and turns, quite unanticipated by the theoretical literature, to the discourse and performance of cosmopolitanism in the Balkan semiperiphery. One of them is the legacy of socialist Yugoslavia which was in its own way cosmopolitan, both as a founder of the non-aligned movement and a well-connected member of the international community, and through the antinationalism of its legitimating ideology. Some positive memory of this remains, especially in those post-Yugoslav countries that have experienced a sharp deterioration in their international status after 1991, such as Serbia, Bosnia-Herzegovina, or Macedonia (Jansen, 2009a, 2009b; Spasić, 2011; Greenberg, 2011). At the same time though, these memories do not easily find a proper discursive frame, since "socialism" has been marked negatively in the dominant public talk of the "transition", as something old and backward, to be left behind. An interesting aspect here is that the SFRY version of cosmopolitanism, anti-Eurocentric and leftist as it was, was distinctly more popular, less class-exclusive, far less connected with cultural distinction, and therefore more readily acceptable among popular strata, than what counts as cosmopolitanism today.

The next twist is due to the region's specific position as to its European core. Cosmopolitanism is here often identified, in the political sphere and cultural debates alike, with a "pro-European" stance - a view favour-

\footnotetext{
${ }^{15}$ And somewhat wryly, Simić (2010: 335) asks: "Who are those 'others' people feel they need to encounter in order to be cosmopolitan? Obviously, they are not our 'inner' others, the peasants from Bosnia or inner Serbia, but 'real' others, like African Americans, who we need in order to be 'cosmopolitan' and who are brought to Serbia to the Exit festival".
} 
ing the country's EU accession, progressive Europeanization of society and voluntary submission to international legal norms and institutions, the most important one being the ICTY, and as against closure, isolation, xenophobia and nationalist exceptionalism. But "Europeanism" itself has its ambiguities, and a "European" identity has its various others that may be picked by the aspiring members of the "European family", with less cosmopolitan outcomes than one may have hoped. If Europe is understood in counterposition to non-White peoples and/or Muslims - and it has been argued that this precisely was the way Europe constituted itself historically (e.g. Mastnak, 2007) - then such hidden layers of "Europe" enable the pariahs of the semiperiphery to claim a very European, even ur-European identity for their collectivities, while retaining racist presumption of privilege, or at least a suspicion of other races and continents. ${ }^{16}$ All peoples at the margins of Europe have developed their versions of antemurale myths, claiming to have defended "Europe" from various evils threatening to destroy it. In the north-western parts of the post-Yugoslav space after 1990, this tendency has been phrased as an "escape" from an Oriental Yugoslavia and a "return" to Europe; in this highly ideologized narrative, the positive import of earlier Yugoslav cosmopolitanism is completely and deliberately cancelled. In Serbia, a pro-European orientation is sometimes expressed in forms that embarrassingly smack of racism. ${ }^{17}$

The other, more complicated possibility is to imagine "Europe" as opposed to "America". In this view, the USA is interpreted as an arrogant superpower bullying weaker states, and an unbridled individualistic capitalism stripped of social solidarity and care. Although this attitude is by no means dominant, especially in official political discourse, it is present at more everyday levels. Antonsich (2008: 511-512) found it distinctly articulated in his empirical study of a "postnational" attitude among EU citizens. Closer to home, a sharp distinction between Europe and the US has recently been put forward by Croatian philosopher Mario Kopić (2010: 15-22), on the basis of their different treatments of the sanctity of human life. In Serbia, whose relations to the West are burdened by the experience of the 1999

${ }^{16}$ For Serbia, an analysis of representations of Europe among the young, vacillating between an "occidentalist" and a more consistently cosmopolitan understanding, may be found in: Radović (2009).

${ }^{17}$ An excellent illustration was provided in early 2011 by the leader of the Liberal Democratic Party, the most vociferously antinationalist and pro-EU force on the Serbian political scene, who derisively described the Foreign Minister's African tour as "meeting with African cannibals". He later apologized, but the impression remains that he had spoken his mind, and that of many of his supporters. 
NATO bombing, the unitary "West" still tends to be broken up into a "Europe", where "we" ultimately belong in spite of all the dilemmas, and an "America", which is unfamiliar and distant, or simply a foe. In the study "Politics and Everyday Life" already referred to, participants described Americans in terms closely resembling those employed by Antonsich's respondents, as cold, calculative, profit-oriented, and prone to using force in international relations (Golubović, Spasić and Pavićević, 2003: 211-217).

\section{Concluding note}

In this briefest closing note, I would like to go back to the literature. With semiperipheral lessons in mind, we may read with different eyes passages such as: "[I]n our thinking, our actions, and our living together, the recognition of otherness and the renunciation of the egoistic insistence on our own interests should be adopted as a maxim" (Beck and Grande, 2007: 71). We may wish to ask why must the "other" in "otherness", and the "we" in "our own interests", be national ones, as is clearly assumed here. If we take these to be also class, geopolitical, civilizational, experiential, ideological, or lifestyle demarcations, then perhaps cosmopolitanism will start pondering more honestly on itself and the way it is discursively constructed and performed in the real life of various concrete social settings. This in turn may make its own exclusions and injustices visible, and hence eliminable so that, indeed, no kind of "egoistic insistence on our own interests" may enjoy the unquestioned sympathy of academics.

\section{REFERENCES}

Antonsich, Marco (2008). "The Narration of Europe in 'National' and 'Post-national' Terms: Gauging the Gap between Normative Discourses and People's Views", European Journal of Social Theory, 11 (4): 505-522. doi:10.1177/1368431008097009

Appiah, Kwame Anthony (2007). Cosmopolitanism: Ethics in a World of Strangers. London: Penguin.

Bakić-Hayden, Milica (1995). "Nesting Orientalisms: The Case of Former Yugoslavia", Slavic Review, 54 (4): 917-931.

Bauman, Zygmunt (1998). Globalization: The Human Consequences. New York: Columbia University Press.

Beck, Ulrich (2002). "The Cosmopolitan Society and Its Enemies", Theory, Culture \& Society, 19 (1-2): 17-44. doi:10.1177/026327640201900101

Beck, Ulrich (2004). "Cosmopolitical Realism: On the Distinction between Cosmopolitanism in Philosophy and the Social Sciences", Global Networks, 4 (2): 131-156. doi:10.1111/j.1471-0374.2004.00084.x

Beck, Ulrich and Grande, Edgar (2006 [2004]). Kozmopolitska Europa: društvo i politika u drugoj moderni. Zagreb: Školska knjiga. 
Beck, Ulrich and Grande, Edgar (2007). “Cosmopolitanism: Europe's Way out of Crisis”, European Journal of Social Theory, 10 (1): 67-85. doi:10.1177/1368431006068758

Beck, Ulrich and Sznaider, Natan (2006). "Unpacking cosmopolitanism for the social sciences: A research agenda", The British Journal of Sociology, 57 (1): 1-23. doi:10.1111/j.1468-4446.2006.00091.x

Becker, Howard S. (1967). "Whose side are we on?", Social Problems, 14 (3): 239-247.

Blagojević, Marina (2009). Knowledge Production at the Semiperiphery: A Gender Perspective. Belgrade: Institut za kriminološka i sociološka istraživanja.

Bourdieu, Pierre (1979). La Distinction: Critique sociale du jugement. Paris: Minuit.

Bourdieu, Pierre (1982). Ce que parler veut dire: L'économie des échanges linguistiques. Paris: Fayard.

Bourdieu, Pierre (1994). Raisons pratiques: Sur la théorie de l'action. Paris: Seuil.

Bourdieu, Pierre (1997). Méditations pascaliennes. Paris: Seuil.

Bourdieu, Pierre (2001). Science de la science et réflexivité. Paris: Raisons d'agir.

Bourdieu, Pierre and Wacquant, Loïc (1999). "On the Cunning of Imperialist Reason”, Theory, Culture \& Society, 16 (1): 41-58. doi:10.1177/026327699016001003

Calhoun, Craig (2002). "The Class Consciousness of Frequent Travelers: Toward a Critique of Actually Existing Cosmopolitanism", South Atlantic Quarterly, 101 (4): 869-897. doi:10.1215/00382876-101-4-869

Calhoun, Craig (2003). "“Belonging' in the cosmopolitan imaginary”, Ethnicities, 3 (4): 531-553. doi:10.1177/1468796803003004005

Calhoun, Craig (2008). "Cosmopolitanism and nationalism", Nations and Nationalism, 14 (3): 427-448. doi:10.1111/j.1469-8129.2008.00359.x

Chernilo, Daniel (2012 /forthcoming/). "Cosmopolitanism in Social Theory: An Ambivalent Defense", in: Roland Robertson and Anne Sophie Krossa (eds). European Cosmopolitanism in Question. New York: Palgrave Macmillan.

Cvetičanin, Predrag and Popescu, Mihaela (2011). "The art of making classes in Serbia: Another particular case of the possible”, Poetics, 39 (6): 444-468. doi:10.1016/j.poetic.2011.09.006

Delanty, Gerard (2009). The Cosmopolitan Imagination: The Renewal of Critical Social Theory. Cambridge: Cambridge University Press.

Fine, Robert and Boon, Vivienne (2007). "Introduction. Cosmopolitanism: Between Past and Future", European Journal of Social Theory, 10 (1): 5-16. doi:10.1177/1368431006068751

Fossum, John Erik (2011). "Review essay: A cosmopolitan constellation?", European Journal of Social Theory, 14 (2): 235-248. doi:10.1177/1368431011403463

Fridman, Viviana and Ollivier, Michèle (2004). "Ouverture ostentatoire à la diversité et cosmopolitisme: Vers une nouvelle configuration discursive?”, Sociologie et sociétés, 36 (1): 105-126.

Friedman, Jonathan (1997). "Global crises, the struggle for cultural identity and intellectual porkbarrelling: Cosmopolitans versus locals, ethnics and nationals in an era of de-hegemonisation", in: Pnina Werbner and Tariq Modood (eds). Debating Cultural Hybridity: Multi-cultural Identities and the Politics of Antiracism. London: Zed Books, pp. 70-89. 
Golubović, Zagorka, Spasić, Ivana and Pavićević, Đorđe (2003). Politika i svakodnevni život: Srbija 1999-2002. Beograd: IFDT and Filip Višnjić.

Greenberg, Jessica (2011). "On the Road to Normal: Negotiating Agency and State Sovereignty in Postsocialist Serbia”, American Anthropologist, 113 (1): 88-100. doi:10.1111/j.1548-1433.2010.01308.x

Hannerz, Ulf (1990). "Cosmopolitans and Locals in World Culture", Theory, Culture \& Society, 7 (2): 237-251. doi:10.1177/026327690007002014

Jansen, Stef (2009a). "Cosmopolitan openings and closures in post-Yugoslav antinationalism", in: Magdalena Nowicka and Maria Rovisco (eds). Cosmopolitanism in Practice. Farnham: Ashgate, pp. 75-92.

Jansen, Stef (2009b). "After the red passport: Towards an anthropology of the everyday geopolitics of entrapment in the EU's 'immediate outside", Journal of the Royal Anthropological Institute, 15 (4): 815-832. doi:10.1111/j.14679655.2009.01586.x

Kendall, Gavin, Woodward, Ian and Skrbis, Zlatko (2009). The Sociology of Cosmopolitanism: Globalization, Identity, Culture and Government. New York: Palgrave Macmillan.

Kopić, Mario (2010). Sekstant: skice o duhovnim temeljima svijeta. Beograd: Službeni glasnik.

Lamont, Michèle and Aksartova, Sada (2002). "Ordinary Cosmopolitanisms: Strategies for Bridging Racial Boundaries among Working-Class Men”, Theory, Culture \& Society, 19 (4): 1-25. doi:10.1177/0263276402019004001

Mastnak, Tomaž (2007). Evropa: istorija političkog pojma. Beograd: Beogradski krug.

Mishkova, Diana (2008). "Symbolic Geographies and Visions of Identity: A Balkan Perspective", European Journal of Social Theory, 11 (2): 237-256. doi:10.1177/1368431007087476

Nussbaum, Martha C. et al. (1996). For Love of Country: Debating the Limits of Patriotism (ed. Joshua Cohen). Boston: Beacon Press.

Olofsson, Anna and Öhman, Susanna (2007). "Cosmopolitans and Locals: An Empirical Investigation of Transnationalism”, Current Sociology, 55 (6): 877895. doi:10.1177/0011392107081991

Petrović, Tanja (2010). "Dugo putovanje kući: reprezentacije 'zapadnog Balkana' u političkom i medijskom diskursu”, Reč, no. 80/26: 67-113.

Pichler, Florian (2009). "“Down-to-Earth' Cosmopolitanism: Subjective and Objective Measurements of Cosmopolitanism in Survey Research", Current Sociology, 57 (5): 704-732. doi:10.1177/0011392109337653

Pollock, Sheldon, Bhabha, Homi K., Breckenridge, Carol A. and Chakrabarty, Dipesh (2000). "Cosmopolitanisms", Public Culture, 12 (3): 577-589.

[Radović, Srđan] Радовић, Срђан (2009). Слике Европе: истраживање представа о Европи и Србији на почетку XXI века. Београд: САНУ, Етнографски институт.

Roudometof, Victor (2005). "Transnationalism, Cosmopolitanism and Glocalization”, Current Sociology, 53 (1): 113-135. doi:10.1177/0011392105048291

Simić, Marina (2010). "Locating Cosmopolitanism: Practicing Popular Culture in Post-socialist Serbia”, Der Donauraum, 50 (3-4): 345-363. 
Skrbis, Zlatko and Woodward, Ian (2007). "The ambivalence of ordinary cosmopolitanism: Investigating the limits of cosmopolitan openness", The Sociological Review, 55 (4): 730-747. doi:10.1111/j.1467-954X.2007.00750.x

Spasić, Ivana (2006). "ASFALT: The construction of urbanity in everyday discourse in Serbia”, Ethnologia Balkanica, 10: 211-227.

Spasić, Ivana (2011). "Smrt Bricea Tatona i uslovni kosmopolitizam socijalističke Jugoslavije”, in: Ines Prica and Tea Škokić (eds). Horror-porno-ennui: kulturne prakse postsocijalizma. Zagreb: Institut za etnologiju i folkloristiku, pp. 51-69.

Szerszynski, Bronislaw and Urry, John (2002). "Cultures of cosmopolitanism", The Sociological Review, 50 (4): 461-481. doi:10.1111/1467-954X.00394

Todorova, Maria (1999 [1997]). Imaginarni Balkan. Zemun: Biblioteka XX vek.

Turner, Bryan S. (2002). "Cosmopolitan Virtue, Globalization and Patriotism", Theory, Culture \& Society, 19 (1-2): 45-63. doi:10.1177/026327640201900102

Vertovec, Steven and Cohen, Robin (eds) (2002). Conceiving Cosmopolitanism: Theory, Context, and Practice. Oxford: Oxford University Press.

Vidmar Horvat, Ksenija (2011a). "From Metics to the Erased, or How to Ground Cosmopolitanism: A Post-Socialist Perspective on Current Theories of Cosmopolitanism”, Revija za sociologiju, 41 (1): 9-26. doi:10.5613/rzs.41.1.2

Vidmar Horvat, Ksenija (2011b). "Patriotic Cosmopolitanism? Rethinking Cosmopolitanism from a Western Balkan's Perspective", The international conference Cosmopolitanism in a Wider Context: Conceptualizing Past and Present, Stockholm (Södertörn University), 24-26 November 2011, http://webappo.web.sh.se/ p3/ext/res.nsf/vRes/cbees_engelsk_1318603997907_book_of_abstracts_8th_ pdf/\$File/Book_of_Abstracts_8th.pdf (23.11.2011).

Waldron, Jeremy (2000). "What is Cosmopolitan?", The Journal of Political Philosophy, 8 (2): 227-243. doi:10.1111/1467-9760.00100

Weenink, Don (2008). "Cosmopolitanism as a Form of Capital: Parents Preparing Their Children for a Globalizing World", Sociology, 42 (6): 1089-1106. doi:10.1177/0038038508096935

Werbner, Pnina (1999). "Global pathways: Working class cosmopolitans and the creation of transnational ethnic worlds”, Social Anthropology, 7 (1): 17-35. doi:10.1111/j.1469-8676.1999.tb00176.x

Woodward, Ian and Skrbis, Zlatko (2006). "Strategic cosmopolitanism: Investigating the limits of cosmopolitan openness", Paper presented at the annual meeting of the American Sociological Association, Montreal, Canada, August 11, 2006, http://www.allacademic.com/meta/p_mla_apa_research_citation/1/0/3/8/4/p103848_index.html (09.03.2011).

Živković, Marko (2011). Serbian Dreambook: National Imaginary in the Time of Milošević. Bloomington: Indiana University Press. 


\section{Kozmopolitizam kao diskurs i izvedba: pogled s poluperiferije}

\section{Ivana SPASIĆ}

Odjel za sociologiju, Filozofski fakultet, Sveučilište u Beogradu, Srbija

ispasic@f.bg.ac.rs

U članku se nudi kritičko iščitavanje novije literature o kozmopolitizmu, iz perspektive teorijski nadahnute Bourdieuom i oblikovane iskustvenim i intelektualnim kontekstom jugoistočne Europe kao poluperiferije. Identificira se nekoliko slijepih mrlja, od kojih je najvažnija nedostatna samorefleksija glavnih sudionika u raspravi o kozmopolitizmu, što rezultira nenamjeravanim slavljenjem onoga što je uobičajeno dostupno samo nekim dijelovima svijeta i samo nekim društvenim slojevima, kao i pratećom devalvacijom drugih ljudi i njihovih manje sretnih životnih svjetova. Umjesto toga, teza je ovoga rada da bi se kozmopolitizam trebao konceptualizirati kao usidrena kategorija, kao specifičan diskurs i izvedba koju uvijek provode određeni akteri, obraćajući se određenoj publici i unutar neke povijesno, kulturno i politički uvjetovane društvene sredine. Tako viđen, on prestaje biti nečim neizostavno moralno pohvalnim i podrazumijeva vlastita isključivanja i nepravde.

Ključne riječi: kozmopolitizam, poluperiferija, univerzalizam, diskurs, izvedba, distinkcija 